\title{
ИНТЕРЬЕРНОЕ И ЭКСТЕРЬЕРНОЕ ПРОСТРАНСТВО ЕРЕВАНСКОГО ГОСУДАРСТВЕННОГО УНИВЕРСИТЕТА: ОПЫТ СЕМИОТИЧЕСКОГО ОПИСАНИЯ
}

\author{
Т. С. Симян \\ Ереванский государственный университет, Армения \\ tsimyan@ysu.am
}

В статье проводится семиотически-типологический анализ университетского пространства Ереванского государственного университета (ЕГУ). Данное исследование является продолжением дискурса «Университетское пространство». Культурные артефакты ЕГУ описываются не с точки зрения культурно-исторического подхода, а с исподьзованием семиотического метода. Детально описывается пространственное «начало» университетского экстерьера, выявляются семантические и парадигматические особенности центральной скульптуры, а также интерьерный барельеф библиотеки ЕГУ и средневековые маркеры университетского пространства. Центральное пространство Ереванского государственного университета семиотизировано раздичными скульптурами, памятниками, барельефами, являющимися знаками социальной и культурной памяти, отсылающей к разным культурным пластам: от Средневековья до советской эпохи. «Начало» университетского пространства маркируется кдючевыми фигурами армянской письменности, ставшими культурными константами интерьерного и экстерьерного пространства ЕГУ. В визуализации истории превалируют образы видных деятелей армянской средневековой университетской традиции. Изображённые фигуры Месропа Маштоца и Саака Партева отсылают к прошлому, на прагматическом уровне указывая на древность армянского алфавита и глубокие корни армянской схоластической университетской истории. Кроме средневековых деятелей культуры, в университетском пространстве представлены также видные деятели новой и новейшей армянской дитературы (Абовян, Налбандян, Туманян, Чаренц), сыгравшие важную роль в становлении общественной и литературной жизни, приведшие к европеизации армянской литературы, а также к парадигматическим культурным переходам. Анализ эмпирического материла показал, что диапазон исторических артефактов вбирает в себя также и советскую эпоху (соцреализм). Подробный анализ барельефа соцреализма показал, что он явдяется стереотипным артефактом советской эпохи, пропагандистской визуализацией советской тотадитарной идеологии.

Ключевые слова: семиотика пространства, университетское пространство, Ереванский университет, визуальный семиозис, Месроп Маштоц, Саак Партев, соцреализм. 


\title{
INTERIOR AND EXTERIOR SPACE OF YEREVAN STATE UNIVERSITY: SEMIOTIC ASSESSMENT
}

\author{
Tigran Simyan \\ Yerevan State University, Armenia \\ tsimyan@ysu.am
}

The article is semiotic-typological analysis of Yerevan State University (YSU) interior space and external grounds. It is a part of Yerevan City discourse, which depicts separate part of Yerevan downtown, and fragments of the interior and exterior space of YSU. Moreover, this article is a continuation of the discourse "University Space". YSU cultural artifacts are described both by culturalhistorical as well as by a semiotic method. Russian reviews have described the semiotically labeled spaces of the university mainly by a cultural-historical approach. The cultural environment has become the meta-language concept of this approach. The cultural-historical methodology does not imply a semiotic metalanguage and analysis. This reveals psychological and cultural values, different historical eras and signs of identity, etc. The article is a detailed description of the starting point of the university exterior grounds represented by the central sculpture, interior works of art and bas-relief of the YSU Library. The central space of Yerevan State University is semiotized by various sculptures, monuments, and bas-reliefs. These are signs of social and cultural memory, referring to different cultural eras: from the Middle Ages to the Soviet Empire. The principal sculpture of the university garden represents the founder of Armenian alphabet Mesrop Mashtots and other prominent representatives of the Armenian medieval university traditions. The figures depicting Mesrop Mashtots and Sahak Partev refer to the past, pointing to the antiquity of the Armenian alphabet and the deep roots of the Armenian scholastic university tradition. Among medieval cultural figures, we see other renowned poets and writers of New and Contemporary Armenian Literature such as Abovyan, Nalbandyan, Tumanyan, and Charents. They played an important role in the formation of public and literary life, leading to the Europeanization of Armenian literature, as well as to paradigmatic cultural transitions. The analysis of empirical material demonstrated that the range of historical artifacts also incorporates the Soviet era (socialist realism). Detailed study of the basrelief of socialist realism showed that it is a stereotypical artifact of the Soviet era, a visual propaganda of Soviet totalitarian ideology.

Keywords: semiotics of space, university space, Yerevan State University, visual semiosis, Mesrop Mashtots, Sahak Partev, socialist realism.

DOI 10.23951/2312-7899-2020-1-104-120 


\section{Введение. Подходы и методы анадиза}

Данное семиотически-типологическое исследование университетского пространства Ереванского государственного университета является продолжением и обогащением темы ереванского городского текста, поскодьку представляет собой сегметированно-фокализированный анализ конкретного и локального университетского интерьерно-экстерьерного пространства. По сути, статья является развитием дискурса «Городской текст Еревана», или «Ереванский текст», в армянском научно-семиотическом поле, которое всё ещё находится в процессе становления и формализации [Долуханян 1997; Степанян, Симян 2012]. Сам дискурс университетского пространства, подходы и методы его анадиза, особенно в оппозиции «университетгород» [см., напр., Аванесов 2019], в русскоязычном научном сообществе впервые был обсуждён на конференции «Визуальная антропология - 2019. Город-университет: жизненное пространство и визуальная среда» в Ведиком Новгороде.

Русскоязычная критическая литература описывает семиотически маркированное пространство университета в основном с позиции культурно-исторического подхода; именно поэтому если и анадизируется университетское пространство, то кдючевым метаязыковым понятием этого анадиза становится «культурная среда». Именно так описывает, например, Поронюк «культурную среду университетского пространства» [Поронюк 2015]. Культурно-исторический подход не предполагает семиотического метаязыка и анадиза, не имеет в виду культурно маркированного семиотизированного пространства. Подобный подход бодьше отвечает на вопросы «что» и «когда»; семиотический метод, благодаря разным измерениям (семантическому, прагматическому, синтагматическому, парадигматическому и т. д.), отвечает как минимум на вопросы «как», «почему» и выявляет неосознаваемые общественные, психологические структуры, ценности, виды памяти, механизмы запоминания и забвения, знаки идентичности и т. д.

\section{От экстерьера к интерьеру}

Рассмотрим вначале культурные семиотизированные «маркеры» - скульптуры на территории ЕГУ. Прямо перед центральным зданием (ил. 1) стоит памятник, посвящённый армянским священнослужителям Сааку Партеву и Месропу Маштоцу; благодаря по- 
следнему в начале V в. был создан армянский алфавит. Скульптура была установлена перед университетом в 2002 году. Она является увеличенной репликой микроварианта, созданного в 1943 г. армянским скульптором Ара Саргсяном (1902-1969). Если прочесть скульптуру вне контекста университета, то памятник в прагматическом плане напоминает студенту о двух великих культурных деятелях средневековой Армении. Если памятник читается в синтагматической фразе «памятник - центрадьное университетское здание», то пространственное «начало» университета раскрывается в дидактическом модусе. Смысл в том, что культурный «вход» в университет возможен тодько после знания армянских кодов (букв, слов, текстов и т. д.). Иными словами, тодько после изучения (армянского) языка, после познания «первичной моделирующей системы» (Ю. Лотман) можно перейти к следующему уровню - к познанию науки, войти в «кузницу» учителей, исследователей, учёных. Аишь после усвоения языка студент может приступить к изучению метаязыка - языка науки, а также приступить к постижению «вторичных модедирующих систем» (религия, литература, лингвистика, искусство, философия и т. д.) $)^{1}$.

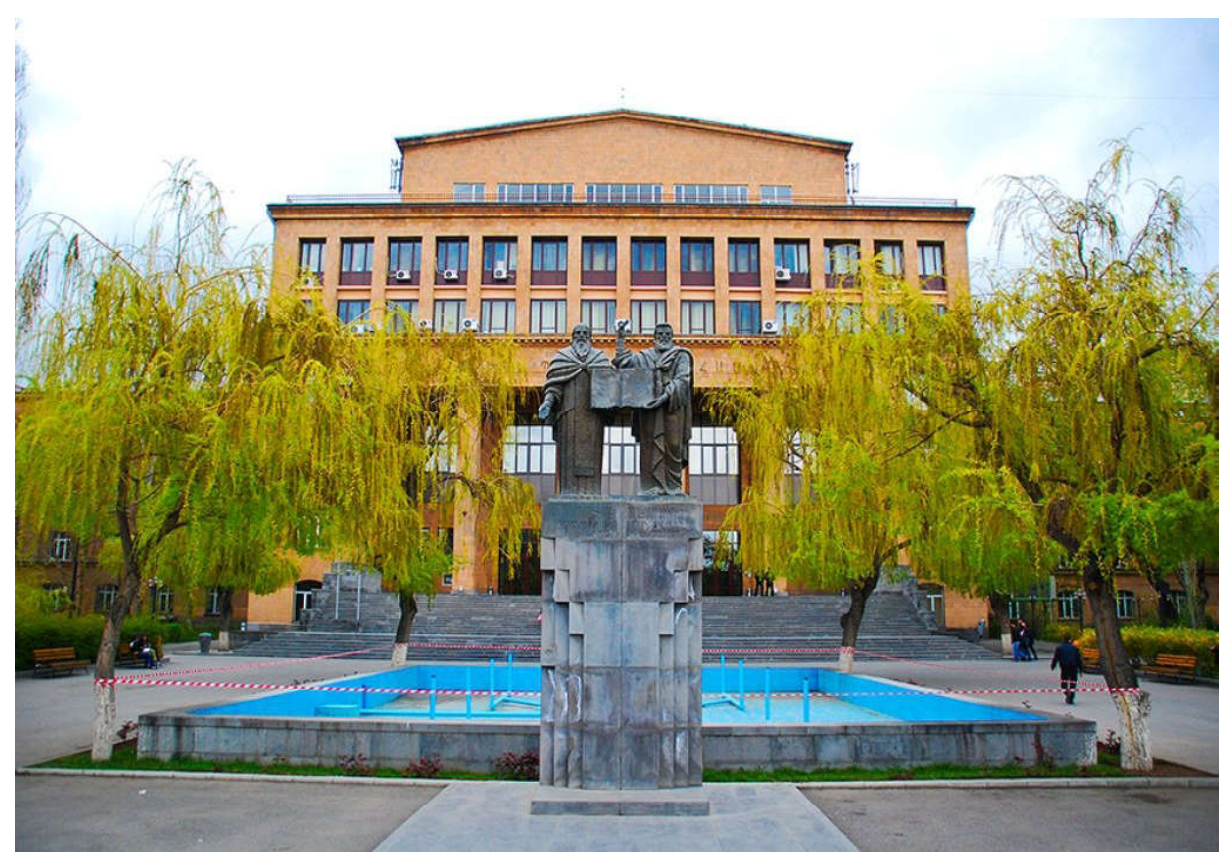

Ил. 1. Главный корпус Ереванского университета.

Источник: https://avproduction.am/?ln=en\&page=culture\&id=18

${ }^{1}$ См. об этом подробнее: Дотман 1965. 
Дидактические мотивы в университетском пространстве можно увидеть на барельефной стене спортивного зала ЕГУ (ил. 2). Визуализацию сцены «орёл, кормящий своего птенца» можно интерпретировать в разных кодах. Университет-орёл кормит знаниями своих орлят, птенцов-студентов. Если проанадизировать изображение в чисто биодогическом ключе, то здесь можно видеть норму, согласно которой каждый должен заботиться о своём будущем потомстве. А если рассмотреть сцену в контексте ещё одной функции фойе спортивного зала ЕГУ, где работает приёмная комиссия, то для реципиента активируется код заботы: сотрудники приёмной комиссии готовы помочь своими советами абитуриентам. Тем самым барельеф приобретает для разных реципиентов неодинаковые значения, становясь знаком-означающим для раздичных означаемых.

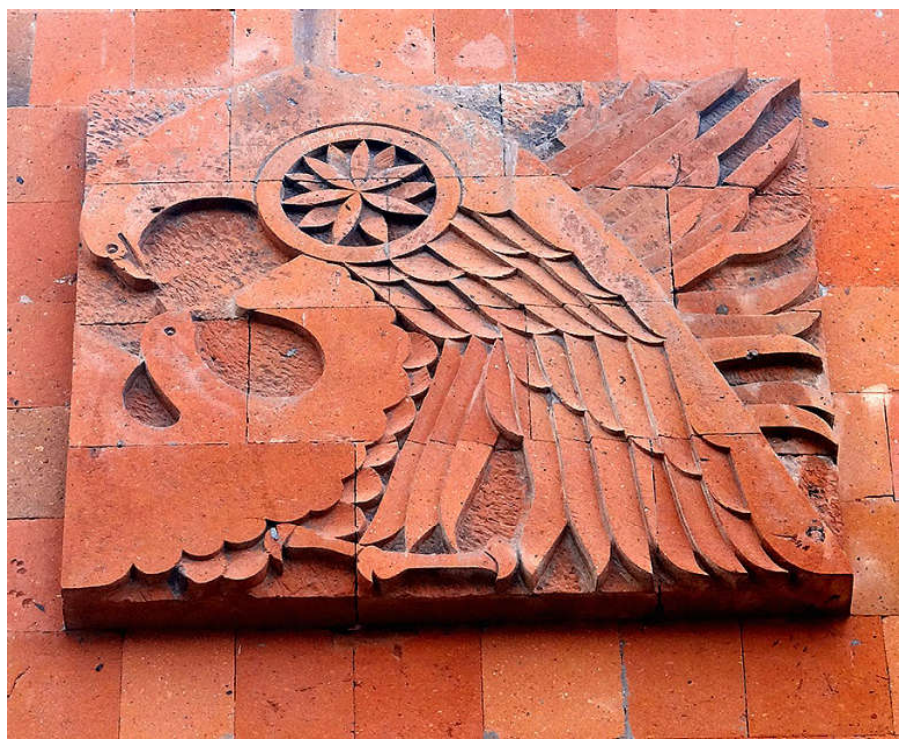

Ил. 2. Орёл и орлёнок. Фото: Тигран Симян, 2019

Вернёмся теперь к анализу ключевой скульптуры - Месропу Маштоцу и Сааку Партеву. Поднятая правая рука Месропа Маштоца (361-440) указывает на «правое» дело, которое, наконец, свершилось, а открытая ладонь правой руки католикоса Саака Партева (338-439) отсылает к открытости: письмена с открытым сердцем вручаются народу. Скульптура перед университетом является, по сути, «пересмотром» скрытого ментального кода советской эпохи. Сказанное интерпретируем в историко-типологическом плане. Перед зданием Матенадарана (Институт древних рукописей) расположен 
памятник Месропу Маштоцу и его ученику - Корюну (1967)², скульптура акцентирует оппозицию «учитель vs ученик»; университетская же скульптура - оппозицию «архимандрит (Месроп Маштоц) vs катодикос (Саак Партев)». На трансформацию ментального кода впервые обратил внимание антрополог Девон Абрамян. Как было метко им отмечено, роль армянского католикоса и царя Врамшапуха (389 или 400-414) в советское время умалялась [Абрамян 2011, 93], а установление скульптуры перед университетом можно рассматривать как «пересмотр» всего организационного процесса изобретения армянской письменности ${ }^{3}$, поскодьку в постсоветскую эпоху на подсознатедьном уровне произошла десекуляризация сознания и оппозиция «учитель vs ученик» сменилась на другую оппозицию - «католикос vs архимандрит». В этом противопоставлении акцентируются духовные деятели и косвенно подчёркивается функция Церкви; изобретение письменности было заказом, проектом, предложенным «сверху» социальным заказом [Абрамян 2011, 92].

К сожалению, в городском пространстве Еревана нигде пока не визуализированы все «авторы» изобретения письменности в тернарной оппозиции: царь - католикос - архимандрит (Врамшапух - Саак Месроп), хотя, как отмечает А. Абрамян, «в конкурсах постсоветского времени на памятник, который заменид бы низвергнутого Денина на площади Республики (бывшей площади Яенина), было несколько проектов, где Маштоц был уже в компании католикоса Саака Партева и царя Врамшапуха» [Абрамян 2011, 93]. Но как показывает эмпирическое наблюдение, это место не загромождено культурными знаками, оно в летнее время покрыто травой и цветами.

Перед центральным входом университета слева и справа (ил. 3-4) стоят памятники армянскому средневековому историку Мовсесу Хоренаци (V в.) и математику, картографу, астроному, алхимику, основателю древнеармянского естествознания Анании Ширакаци (VII в.). Расположение скульптур в общем плане указывает на расположение факультетов по правую и девую стороны здания. На правой стороне находятся факультеты фундаментальных наук (факультет радиофизики и физики, информатики и прикладной математики и факультет математики и механики), а на левой стороне от центрадьного здания - юридический факультет, факультет международных отношений, факультет русской филологии, факультет востоковедения, факультет европейских языков и коммуникации.

\footnotetext{
${ }^{2}$ О семиотическом аспекте этого пространства см.: Степанян, Симян 2012, 9-11; Долуханян 1997, 99.

${ }^{3}$ Об истории сознания армянской письменности см. подробно статью Альберта Мушегяна: Мушегян 2006.
} 

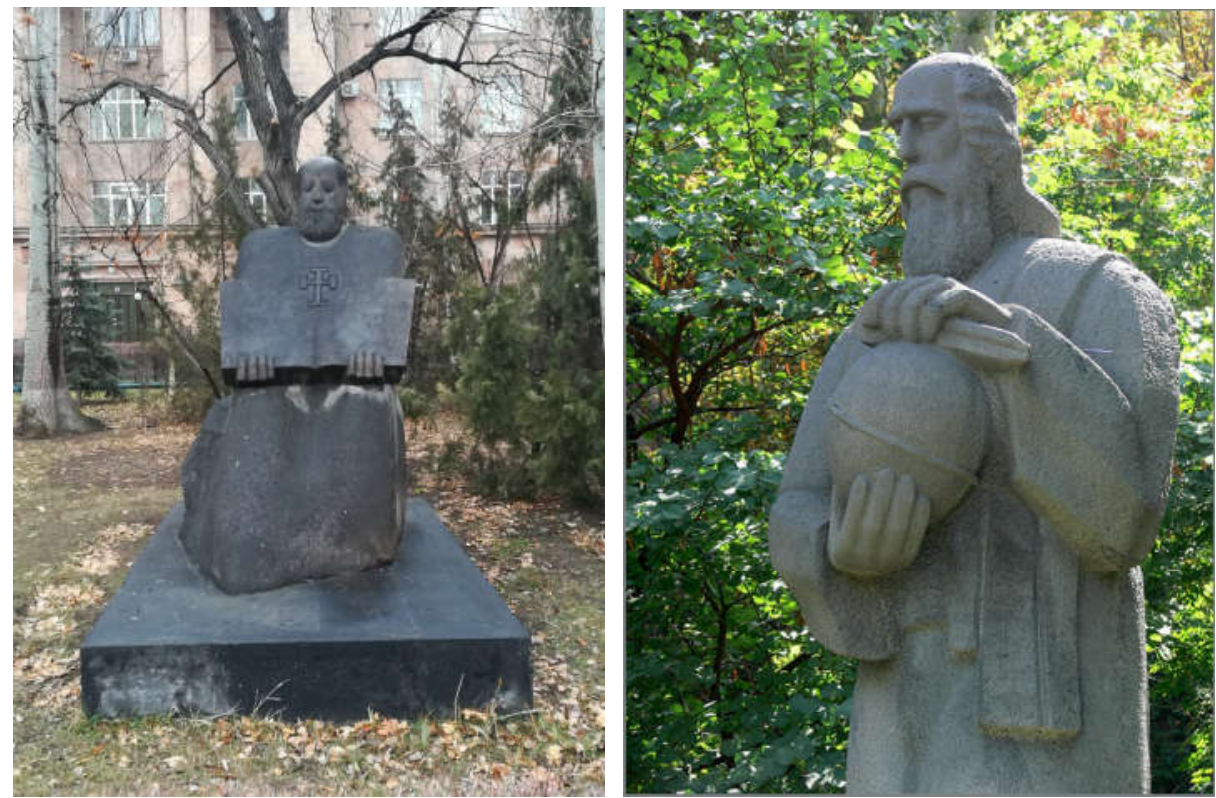

Ил. 3-4. Памятники М. Хоренаци (слева) и А. Ширакаци. Фото: Тигран Симян, Сергей Аванесов, 2019

Если прочесть университетское визуальное пространство от памятника Сааку Партеву и Месропу Маштоцу через центральное здание к Аллее Благодарности (посвящённой европейцам, помогавшим Армении), которая находится за центральным зданием университета, то у нас получится тернарная синтагматическая фраза с двумя деталями экстерьерного пространства (скульптура и аллея) и одного интерьерного (центральное здание ЕГУ). Таким образом, в целом получается следующая пространственная синтагматическая фраза: памятник Сааку Партеву и Месропу Маштоцу - центральное здание (библиотека и музей университета) - Алдея Благодарности.

\section{Пространство библиотеки ЕГУ и средневековые маркеры университетского пространства}

Строительство здания библиотеки ЕГУ было начато в 1984 г. (архитектор Левон Бабаян, скульптор Ваган Казарян), а 12 октября 1994 г., в год 75-летия основания университета, строительство нового здания было завершено [Симонян 2018, 223]. Собранная дитература (свыше 2 млн книг) и доступ к электронным ресурсам позводяет бибдиотеке 
ЕГУ быть не только хранилищем национальной культурной памяти, но и частью транснационального культурного наследия.

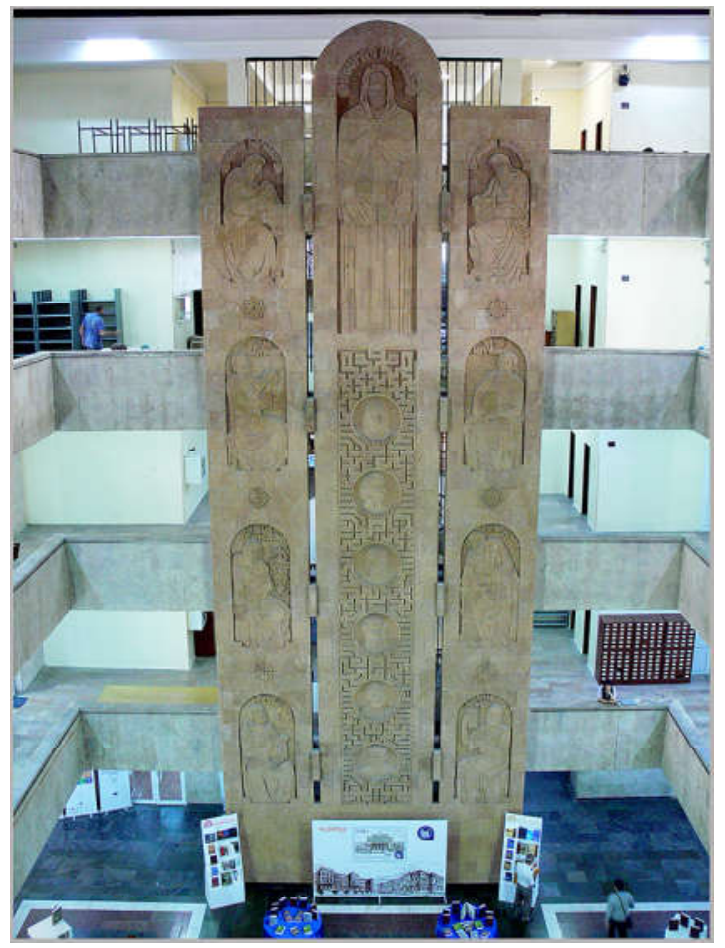

Ил. 5. Интерьер библиотеки. Фото: Сергей Аванесов, 2019

В семиотическом плане интересен барельеф в фойе библиотеки (ил. 5). Следует заметить, что сам материал барельефа отсылает к феномену армянскости, поскольку армянский туф является одним из традиционных и легко узнаваемых строительных и облицовочных материалов Армении. Список изображённых на барельефе фигур:

\begin{tabular}{|c|c|c|}
\hline Мовсес Хоренаци (V в.) & Месроп Маштоц (V в.) & Давид Анахт (V-VI вв.) \\
\hline Анания Ширакаци (VII в.) & Торос Рослин (XIII в.) & Григор Нарекаци (X-XI вв.) \\
\hline Ованес Имастасер (XI в.) & Акоп Мегапарт (XV-XVI) & Мхитар Гераци (XII-XIII) \\
\hline Мхитар Гош (XIII в.) & Хачатур Абовян (XIX в.) & $\begin{array}{c}\text { Григор Татеваци } \\
\text { (XIV-XV в.) }\end{array}$ \\
\hline & $\begin{array}{c}\text { Микаэл Налбандян } \\
\text { (ХIX в.) }\end{array}$ \\
\hline & Ованес Туманян (XX в.) \\
\hline & Егише Чаренц (XX в.) \\
\hline
\end{tabular}


Само расположение средневековых учёных справа и слева по принципу витражного моделирования является косвенной отсылкой к средневековым университетским традициям: Санаинской (966), Анийской (XI в.), Гладзорской (1284) ${ }^{4}$, Татевской (1390) и т. д.. ${ }^{5}$, поскодьку изображённые средневековые учёные были выпускниками этих университетов. В центре сверху плиты представлен Месроп Маштоц. По замыслу скульптора барельефа, семантическая нагрузка в нём концентрируется на верхнем центре, на крупной фигуре Месропа Маштоца.

Если изображённые фигуры деятелей средневековой культуры и естествознания справа и слева просто отсылают к высокому уровню средневековой культурной и научной традиции без какого-дибо семантического противопоставления противоположных фигур, то расположение образов по центру семантически нагружено в нескольких смыслах. Изобретатель письменности Маштоц, художник-миниатюрист, крупнейший представитель армянской Киликийской школы миниатюры Торос Рослин и Акоп Мегапарт, издавший в 1512 г. в Венеции первую армянскую печатную книгу «Книга пятниц» (Урбатагирк), семантически связаны друг с другом. Их деятельность имеет отношение к письменности: к рукописи и печатной книге, к символическим (алфавит, слово) и иконическим (миниатюра) знакам, что и акцентировано путём их совместного изображения. Кроме того, барельеф на прагматическом уровне становится культурным «мостом» между богатой университетской традицией средневековой Армении и современностью.

Армению Нового времени представдяют здесь четыре известных деятеля армянской культуры и литературы по центру, ниже Акопа Мегапарта: писатель Хачатур Абовян (1809-1848) как основатель новой армянской дитературы, поэт, критик; публицист Микаэл Надбандян (1829-1866) как носитель «проекта Просвещения», демократ; а также два крупнейших национадьных поэта - Ованес Туманян (1869-1923) и Егише Чаренц (1897-1937). Армянский писатель начала XX века Егише Чаренц представлен в университетском пространстве не только на барельефе библиотеки ЕГУ, но и на улице Чаренца. В его честь назван книжный магазин в виде книги (ил. 6) на котором написаны слова поэта: «Умение чувствовать красоту -

\footnotetext{
${ }^{4}$ См. подробнее: Абрамян 1983; Гарибян 1983; Гарибджанян 1986.

${ }^{5}$ См. подробнее: Гарибджанян 1971, 9-15; Аревшатян, Матевосян 1984; Гарибджанян 1986; Азатян 2009, 10-12; Бархударян 2013, 3-21.

6 Заметим, что в центре Еревана на центральных улицах, названных в честь армянских поэтов, можно увидеть подобные книжные магазины, например, имени Ваана Терьяна (18851920) и т. д.
} 
только одна часть таланта писателя. Без неё нет настоящего поэта». Адресатом приведённого текста являются проходящий мимо студент, преподаватель и т. д. Высказывание раскрывает самого поэта, его творческую аксиологию, а также «поэтику» - умение чувствовать красоту. Одним из потенциальных смыслов фразы «умение чувствовать красоту - только одна часть таланта писателя» в контексте университетского пространства можно считать намёк ещё и на ум, интеллект. Иными словами, для полноценной жизни, кроме науки, нужно уметь чувствовать красоту.

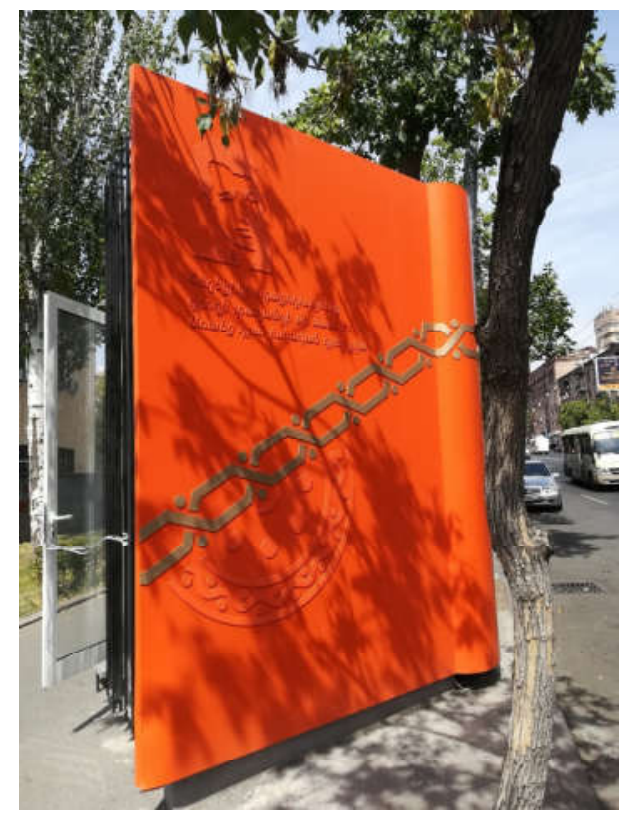

Ил. 6. Киоск в виде книги. Фото: Тигран Симян, 2019

Отметим, что средневековые деятели армянской филологии визуадизированы и представдены в фойе здания на первом этаже на досках-барельефах работы Левона Токмаджяна (род. 1937). На этой синтагме в центре снова представлен изобретатель письменности Месроп Маштоц. Справа от него представлены Григор Нарекаци (X в.), Комитас (XX в.) и Егише Чаренц (XX в.), слева - Мовсес Хоренаци (V в.), Хачатур Абовян (XIX в.), Ованес Туманян (XX в.) $)^{7}$. По логике синтагмы можно вывести, что от «центра» - Месропа Маштоца - удаляются согласно хронологии ключевые деятели армянской культуры.

\footnotetext{
7 На втором этаже здания филологического факультета можно увидеть также портрет армянского критика и политического деятеля Никола Агбаляна (1875-1947), а напротив, на стене - портреты преподававшей профессуры.
} 


\begin{tabular}{|c|c|c|c|c|c|c|}
\hline Ованес & Хачатур & Мовсес & Месроп & Григор & Комитас & Егише \\
Туманян & Абовян & Хоренаци & Маштоц & Нарекаци & & Чаренц \\
XX в. & XIX в. & V в. & «центр» & Х в. & XX в. & XX в. \\
\hline
\end{tabular}

Подводя промежуточный итог, подчеркнём, что фигура Маштоца становится парадигмообразующей основой, «притягивающей» все остальные фигуры не только на барельефе библиотечного здания, но и в фойе центрального здания ЕГУ. Иными словами, «центральная» фигура (Месроп Маштоц) притягивает «периферийные» фигуры, «собирает» их около себя. Становится очевидным также, что идея изобретения письменности, образ рукописи/книги и фигура М. Маштоца явдяются архетипически значимыми константами; это выявляется при анализе центральной оси экстерьерного и интерьерного пространства главного корпуса университета и находящегося в нём филологического факультета.

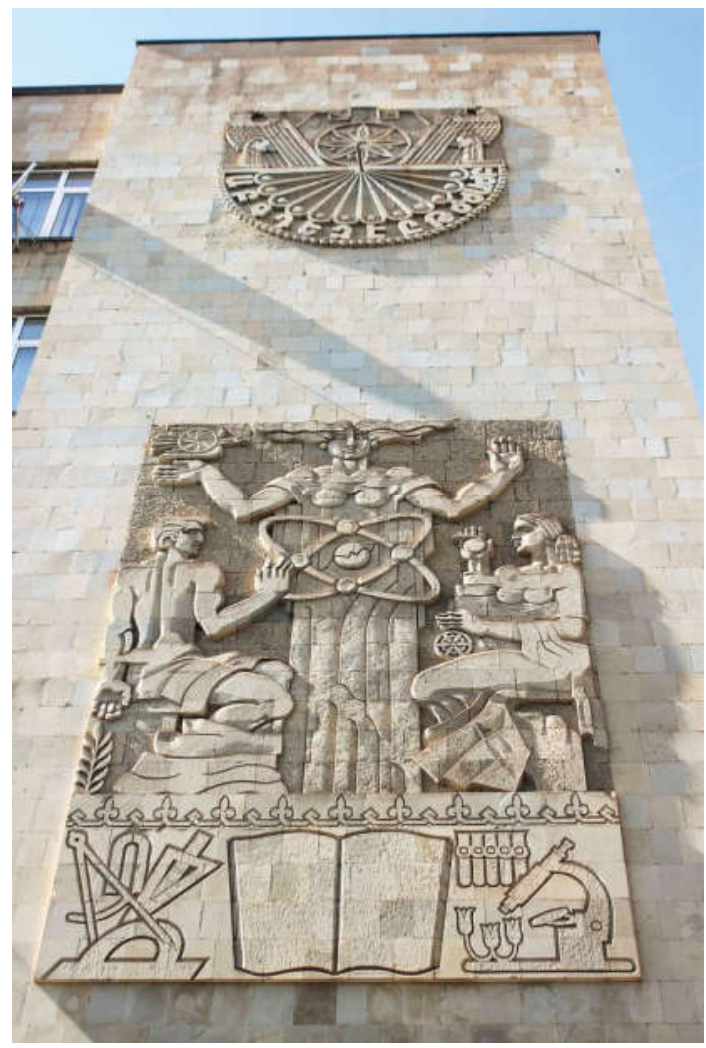

Ил. 7. Солнечные часы и барельеф «Наука».

Источник: https://www.panorama.am/ru/news/2019/02/23/Солнечные-часы-Звартноц/2076856 
В университетском пространстве ЕГУ можно увидеть ещё одну отсылку к средневековой традиции. Здесь представлен принцип определения времени. Вертикальные солнечные часы с армянскими буквами-цифрами можно увидеть на здании гуманитарных факультетов ЕГУ, ближе к выходу на улицу Чаренца (ил. 7). На иллюстрации по гномону чётко прочитывается время. Тень падает на армянскую букву «Ж» (б). Если отсчёт начинается с буквы «U» армянского алфавита («А» значит 7, «Б» -8 и т. д.), то, соответственно, буква «б» указывает на 16.00. В Средневековье солнечные часы высекались на южных стенах церквей, чтобы священнослужители могли структурировать и планировать время и для проведения богослужения. В нашем контексте солнечные часы на здании гуманитарных факультетов одновременно отсылают к средневековой традиции естественных наук и культуры, поскодьку вертикальные солнечные часы были ещё и архитектурными декорациями, эстетическими знаками, в которых можно увидеть разные языки декораций․

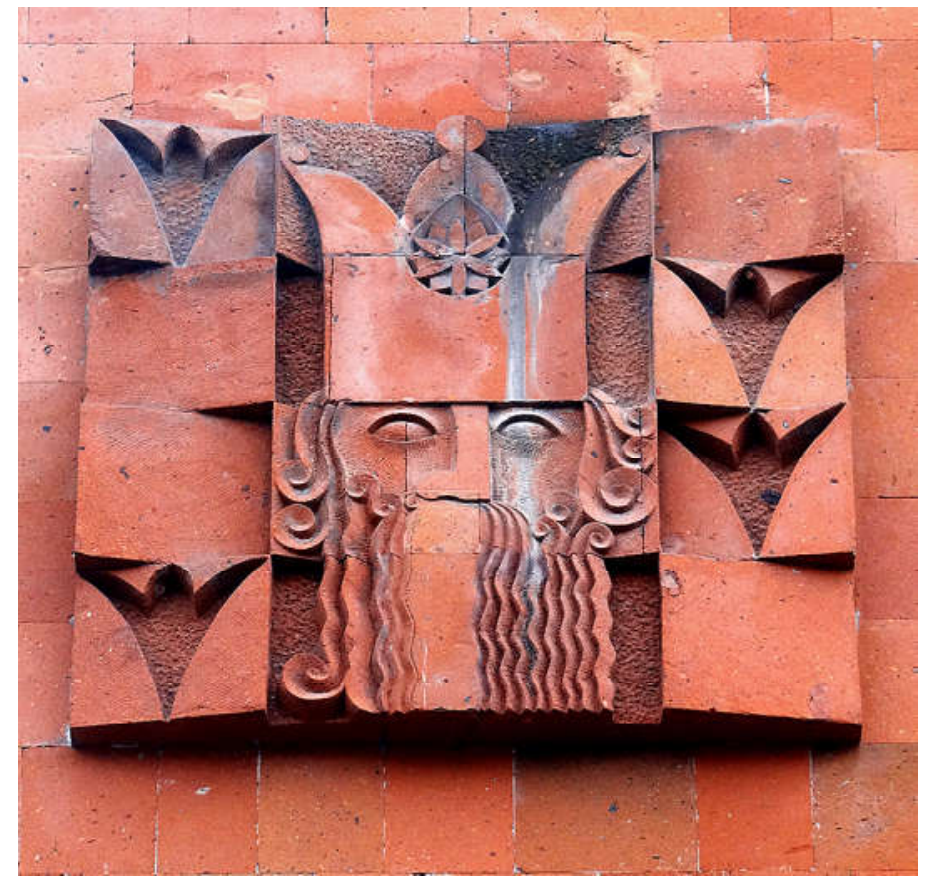

Ил. 8. Царь Аргишти І. Фото: Тигран Симян, 2019

\footnotetext{
8 Заметим, что солнечные часы могут иметь не только утилитарное значение, но также дать повод подумать о потусторонней жизни. Например, на стене протестантской церкви Св. Георгия на площади Марктплац в городе Гайде (Шлезвиг-Гольштейн) под солнечными часами написано: «Моё время в Твоих руках» (Meine Zeit steht in deinen Händen), что для реципиента становится поводом дия осмысления своей временной жизни.
} 
Конечно, армянское средневековье - не единственная эпоха, которая визуализирована или представлена через образы раздичных учёных. В университетском пространстве активно представлена эпоха Урартского царства благодаря барельефу Аргишти I (786-764 гг. до Р. Х.) на стене здания спортзала ЕГУ (ил. 8)9. Царь Аргишти I стал важной политической фигурой, расширившей границы Урартского царства и основавший город Эребуни (782 г. до Р. Х.). Университетский барельеф является копией подлинника, который можно увидеть на фасаде здания музея Эребуни. Барельеф царя Аргишти I в университетском пространстве на внешней стене спортзала ЕГУ указывает больше на духовную, чем на физическую силу. Иными словами, барельефами орла, кормящего своего птенца, изображением головы урартского царя на том же здании моделируется аура силы. В прагматическом плане урартский барельеф отсылает к сильному историческому прошлому и одновременно становится ддя реципиента поводом для вдохновения, поднятия духа. Но все эти коды и идеи становятся активными тодько в том случае, если реципиент барельефа знает о деяниях царя Аргишти.

\section{Советский маркер в университетском пространстве}

Заметим, что в университетском пространстве можно увидеть «след» советской эпохи в виде баредьефа на здании гуманитарных факультетов, расположенного ниже, чем описанные ранее солнечные часы и выступающего как его «продолжение» (см. ил. 7). На синтагматическом уровне здесь очевиден временной экдектизм: если первое (часы) отсылает к армянской национальной научной средневековой традиции, то второе - к советской, транснационадьной. Барельеф, изображающий три фигуры, исполнен в стиле соцреализма.

Адресатами данного барельефа являлись все учащиеся и трудящиеся советского общества. Барельеф в советскую эпоху был артефактом советского искусства и одновременно имплицитной социально-политической «рекламой», визуальным каналом пропаганды. В нынешнее время барельеф может рассматриваться как «ода» науке, хотя для современного реципиента (особенно студента) многие коды соцреализма незнакомы, неактивны. На барельефе справа и слева изображены мужчина и женщина как равноправные пред-

\footnotetext{
${ }_{9}^{9}$ Автор статьи благодарен искусствоведу Сейрануш Манукян, подсказавшую, кто именно представлен на барельефе.
} 
ставители рабочего класса-мессии. В нижней части барельефа изображены циркуль, разные виды линеек, а под фигурой женщины микроскоп, цветы. «Вещный» мир указывает на прикладные и фундаментальные науки (архитектура, биология и т.д.). Синтагма «микроскоп - цветы» связана с контекстом функционирования барельефа, поскольку рядом со зданием филологического факультета находится биологический факультет. Потенциальными реципиентами барельефа являются и студенты, и преподаватели биологического факультета, хотя он не виден от центрадьного входа в здание факультета.

По центру барельефа представлены книга и женщина, а также солнечная система. Семантическая связь солнца и женщины, олицетворяющей науку, с акцентировкой женских половых признаков придаёт барельефу визуальную теплоту, эротический подтекст, хотя мужеподобная эротичность одновременно «нейтрализуется» её маскулинными руками и ярко выраженным кадыком. Руки женщины-науки функционируют одновременно как метафора науки. Иными словами, наука-женщина со своими сильными руками готова принять в свои объятия любого. «Противоречивые» маскулиннофемининные детали тела на прагматическом уровне для реципиента становятся причинами амбивалентного восприятия барельефа, чтобы взгляд останавливался на женских деталях и в то же время внимание рассеивалось. Эротизм в барельефе функционирует на уровне частичной наготы мужского и женского тел. Они на барельефе смоделированы на основе бинарной оппозиции «мужское vs женское» (мускулы vs грудь).

На барельефе акцентирована также «плодовитость» науки. Эта идея передаётся несколькими сегментами, деталями - такими, как пшеница под рукой мужчины, яблоко в руке женщины. Ключевым на барельефе является также бесконечность науки, которая выражена кругообразными декорациями на коленях женщины и на теле несущейся в сторону женщины-науки орлёнка. Последнего можно интерпретировать двояко: или как человеческую волю, влекущую в сторону матери-науки, или как олицетворение духа науки, летящего в будущее - слева направо. Такая интерпретация иегитимна в тех обществах, которые пишут слева направо.

Барельеф выдержан в правилах философии соцреализма, так как он передаёт дух советской эпохи, оптимизм по поводу исторического будущего. Иначе говоря, здесь мы наблюдаем визуальное моделирование коммунистического будущего на основе научных изобретений, научных революций. Язык соцреализма, идеологические 
коды и общие принципы построения подобных визуадьных артефактов можно увидеть на огромном пространстве стран бывшего «социалистического лагеря», от Еревана до Берлина ${ }^{10}$, где для зрителя чётко вырисовывается дидактический и одновременно утопический код идеологии коммунизма - «светлое будущее человечества».

Как видно из проведённого выше анадиза, соцреадистический барельеф, по сути, является социальной рекламой для последующих поколений, как идеадизированный конструкт построения социалистического строя и продвижения «незавершённого проекта» модерна (Ю. Хабермас). Иначе формулируя сущность сказанного, можно утверждать, что барельеф сам по себе становится каналом пропаганды, а на нынешнем этапе в контексте городского пространства ЕГУ функционирует как «безмолвный» знак ушедшей в прошлое советской эпохи.

\section{Закдючение}

Таким образом, можно закдючить, что центрадьное пространство Ереванского государственного университета семиотизировано раздичными скульптурами, памятниками, барельефами и т. д. Все семиотизированные артефакты, фигуры и изображения являются знаками социальной и культурной памяти, отсылающие к разным культурным пластам - от Средневековья до советской эпохи. «Начало» университетского пространства маркируется кдючевыми фигурами армянской письменности как культурными константами интерьерного и экстерьерного пространства ЕГУ. Эмпирический материал показал, что объектами визуализации становятся в основном видные деятели армянской средневековой университетской традиции. Изображённые фигуры отсылают к прошлому, тем самым на прагматическом уровне указывая на древность армянского алфавита и глубокие корни армянской схоластической университетской традиции. Университетское семиотическое пространство также предоставдяет своему реципиенту возможность войти в диалог с культурным прошлым на уровне определения времени по солнечным часам, что, по сути, становится ещё одной отсылкой к богатой армянской средневековой традиции.

\footnotetext{
10 Общность идеологических кодов можно увидеть и на примере мозаики Вальтера Вомачки «Наша жизнь» (1964) в Берлине (https://www.museum-der-1000-orte.de/kunstwerke/kunstwerk/ unser-leben).
} 
Кроме средневековых деятелей культуры, в университетском пространстве представдены также видные деятели новой и новейшей армянской дитературы (Абовян, Налбандян, Туманян, Чаренц), сыгравшие важную роль в становлении общественной и литературной жизни, приведшие к европеизации армянской дитературы, а также к парадигматическим культурным переходам. Университетское пространство становится также пространством презентации разных исторических эпох, не только христианского средневековья, но ещё и более древнего периода Урартского царства. Анализ эмпирического материла также показал, что диапазон исторических артефактов вкдючает и советскую эпоху (соцреадизм). Детальный анализ барельефа соцреализма даёт возможность увидеть, что он является культурным атавизмом советской эпохи, пропагандистской визуадизацией советской тоталитарной идеологии, которая не прочитывается в таком качестве современным реципиентом, поскодьку коды соцреадизма сегодня знакомы только узкому кругу специалистов.

\section{БИБЛИОГРАФИЯ}

Абрамян 1983 - Абрамян А.Г. Гладзорский университет. Ереван, 1983. (На арм. языке).

Абрамян 2011 - Абрамян И. Конструктивисты раннего Средневековья: случай Армении // Антропология социальных перемен. Москва, 2011. С. 87-114.

Аванесов 2019 - Аванесов С. С. Университет и формирование урбанистической реальности // ПРАЕНМА. Проблемы визуальной семиотики. 2019. № 3 (21). С. 268-276.

Азатян 2009 - Ереванский государственный университет / Отв. ред. Л. Азатян. Ереван, 2009. (На арм. языке).

Аревшатян, Матевосян 1984 - Аревшатян С. С., Матевосян А. С. Гладзорский университет - центр просвещения средневековой Армении. Ереван, 1984. (На арм. языке).

Бархударян 2013 - Бархударян В. Образование в средневековой Армении: X-XIV века (Краткий очерк) // Историко-филологический журнал. 2013. № 3. С. 3-21. (На арм. языке).

Гарибджанян 1971 - Гарибджанян И. П. Ереванский государственный университет. Ереван, 1971.

Гарибджанян 1986 - Гарибджанян Г. Б. От Гладзора до Ереванского государственного университета. Ереван, 1986. (На арм. языке). 
Гарибян 1983 - Гарибян И. Г. Гладзор: Локация. Раскопки. Эпиграфика. Ереван, 1983. (На арм. языке).

Долуханян 1997 - Долуханян А. К. Взаимодействие архитектуры и изобразительных искусств при формировании городской среды // Вестник общественных наук. 1997. № 3 (96). С. 93-107.

Лотман 1965 - Лотман Ю. М. О проблеме значений во вторичных моделирующих системах // Труды по знаковым системам. Том 2. Тарту, 1965. С. 22-37.

Мушегян 2006 - Мушегян А. Месроп Маштоц и домаштоцовское армянское письмо // Историко-филологический журнал. 2006. № 2. С. 210-236. (На арм. языке).

Поронюк 2015 - Поронюк С. А. Культурная среда университета как объект исследования // Вестник Московского государственного гуманитарного университета имени М. А. Шолохова. Педагогика и психология. 2015. № 3. С. 40-46.

Симонян 2018 - Из истории ЕГУ / Гл. ред. А. Симонян. Ереван, 2018. Степанян, Симян 2012 - Степанян А. А., Симян Т. С. Ереван как семиотический текст (опыт реконструкции «начала» и «конца» проспекта Маштоца) // Критика и семиотика. 2012. № 16. С. 6-16.

Материал поступил в редакцино 05.10.2019 